\title{
Why Hell Is Other People: Distinctively Human Psychological Suffering
}

\author{
Jesse M. Bering \\ Queen's University
}

\begin{abstract}
Just as there is remarkable continuity between the structures, abilities, and behaviors of closely related species, so too are there equally remarkable differences. Because only our species has evolved the social cognitive mechanisms that enable a heightened sensitivity to the minds of others, only our species suffers the psychological consequences. Using Sartre's famous play No Exit to illuminate the interplay between evolved psychology and social conscious experience, I show how theory of mind is both biologically adaptive and the common denominator in distinctively human types of psychological suffering.
\end{abstract}

Keywords: social cognition, theory of mind, evolutionary psychology, loneliness, intersubjectivity

You remember all we were told about the torture chambers, the fire and brimstone, the "burning marl." Old wives' tales! There's no need for red-hot pokers. Hell is-other people!

- the character of Garcin, in Jean-Paul Sartre's No Exit

In his play No Exit, Jean-Paul Sartre (1946/ 1989) introduces us to three characters who find themselves in the unenviable position of having just been cast to hell. There is Garcin, an assassinated left-wing journalist and draft dodger who believes he's in hell because he mistreated his wife; Inez, a sadistic postal worker with a penchant for seducing other women; and Estelle, a pretty pampered debutante who killed her baby and drove the penniless father to suicide. These three characters, strangers to one another, find themselves locked up together in an aesthetically average drawing room with Second Empire furniture. By all appearances, they are each intelligent, sane, and able to think rationally about the situation. For some time after their deaths, they can even continue to observe their friends and loved ones on earth. So how is this hell? Sartre proceeds to paint a scene for the audience that is so disturbing that

Jesse M. Bering, Institute of Cognition and Culture, Queen's University.

Correspondence concerning this article should be addressed to Jesse M. Bering, Institute of Cognition and Culture, Queen's University Belfast, Belfast BT7 1NN, Northern Ireland, UK. E-mail: j.bering@qub.ac.uk it would make even the most rapacious sinner repent if only to escape the unbearable fate of an eternity spent with others.

As a psychologist who studies social cognition within an evolutionary framework, I am drawn to Sartre's play because it serves to elucidate what I believe is a distinctively human type of psychological suffering, one that is social in nature. From a comparative perspective, the vulnerabilities of the characters are ubiquitous among peoples from all human societies but unique among the entire animal kingdom. Through the lens of Sartre's characters, my aim in the present article is to bring to light some sense of what it "feels like" to be a subjective self amidst the company of other subjective selves. Because only our species has evolved the social cognitive mechanisms that enable such a heightened sensitivity to the minds of others, only our species suffers the consequences of these evolved mechanisms. The capacity to think about others' thoughts improved the human condition as well, of course, by enabling our ancestors to share their private worlds and to develop deeply intimate connections with loved ones. These more salubrious effects, however, have already been discussed elsewhere (Damasio, 2002; Snyder \& Lopez, 2007). In contrast, the less attractive consequences of evolved human social cognition on subjective well-being have been inadequately addressed, both conceptually and empirically, so these shall serve as my focus in the present 
article (for related nonevolutionary approaches, see, e.g., Baumeister, 1990; Smart \& Wegner, 2000).

Sartre's existential allegory forces us to examine the subtle ways by which other people, through their sheer being, can cause us great psychological distress. There are no mirrors or windows in the drawing room, sleep is not permitted, and the light is always on. The characters' eyelids are paralyzed, disallowing them even the luxury of blinking. Garcin reacts with muted horror to the prospect of being constantly observed by Inez and Estelle, despite the professed goodwill of both.

GARCIN: Will night never come?
INEZ: Never.
GARCIN: You will always see me?
INEZ: Always.

\section{It's Only in Our Minds?}

Sartre's well-known phrase "existence precedes essence" means that the existence of human beings implies no inherent meaning. We do not exist as a species or as individuals "for" anything in particular, according to Sartre, but rather invent an essential purpose- or borrow it from others-and apply this constructed meaning to our personal existence. There is some tension here, however, with contemporary cognitive science, which is increasingly focused on evolutionary theory. Based on some of his writings, Sartre would likely have agreed that human existence is governed by the same principles of natural selection as is that of any other species. (His refusal to acknowledge a human nature was not anti-Darwinian but rather antitheistic; it was a rejection of the idea that man had a nature predefined by God.) It is unclear, however, how recent findings from an evolutionarily informed cognitive science might have altered his philosophical views.

The fact that we are compelled to think about the meaning of life, particularly in terms of design and purpose, reflects an ancestral past that carved out a specialized human capacity to reason in these terms. It is from this capacity to reason about other minds that we infer design and purpose even when they are not there. Consider, for instance, an example from Existentialism and Human Emotions, where Sartre (1957, p. 14) compares God to a common artisan:
The concept of man in the mind of God is comparable to the concept of paper-cutter in the mind of the manufacturer, and, following certain techniques and a conception, God produces man, just as the artisan, following a definition and a technique, makes paper-cutter. Thus, the individual man is the realization of a certain concept in the divine intelligence.

From a modern scientific perspective, Sartre's "existence precedes essence" is almost certainly correct. Based on the tenets of their trades, evolutionary scientists and existential philosophers agree that there is no special reason that human beings exist. We simply arelike any other organism. Recent evidence suggests, however, that this logical view of human life being without intelligent design is also deeply counterintuitive to human psychology. For example, findings by developmental psychologists reveal a strong, perhaps innate, teleological cognitive bias in children. When given the choice, preschoolers prefer to see rocks, clouds, and animals as being "for" something rather than just existing and, even in adults, escaping this bias requires explicit scientific knowledge (Kelemen, 2004). We may not, therefore, be as free to abandon our beliefs in essential purpose as Sartre's humanistic stance presupposes (Bering, 2006).

The point is that natural selection made our species exquisitely—and painfully-aware of other minds, particularly other human minds (Guthrie, 1993). Consciousness is inescapable. In No Exit, this hyperawareness is evident in Inez's response to Garcin's suggestion that, to avoid unwittingly serving as one another's torturers in hell, each person in the drawing room should stare at the carpet and try to forget that the others are there. Inez quips:

\footnotetext{
How utterly absurd! I feel you there, in every pore. Your silence clamors in my ears. You can nail up your mouth, cut your tongue out-but you can't prevent your being there. Can you stop your thoughts? I hear them ticking away like a clock, tick-tock, tick-tock, and I'm certain you hear mine. [You're] everywhere, and every sound comes to me soiled, because you've intercepted it on its way.
}

Because they are already dead, the characters in No Exit cannot even end the torture by killing one another. Later in the play, when Garcin acts as if to strangle Inez after she so mercilessly torments him where he's most vulnerable (on the issue of his military desertion), she points this fact out to him: 
You're a coward, Garcin, because I wish it. I wish it-do you hear?-I wish it. And yet, just look at me, see how weak I am, a mere breath on the air, a gaze observing you, a formless thought that thinks you. Ah, they're open now, those big hands, those coarse, man's hands! But what do you hope to do? You can't throttle thoughts with hands.

\section{Why Do We Care What Other People Think About Us?}

From about 4 years of age, human beings are capable of thinking about others' beliefs, even when these beliefs are false or differ from one's own beliefs (Flavell, 1999). In No Exit, for example, Garcin glimpses from hell an image of his still-alive wife standing at the entrance to the military barracks where he had been imprisoned prior to his execution. He reasons that she's only doing so because she does not yet know that he is dead. In developmental psychology, this general capacity to reason about others' beliefs is called a theory of mind. It is a "theory" because one can only explain and predict others' behaviors by making causal inferences about their unobservable mental states.

Although some investigators have made the strong claim that only human beings possess a theory of mind, recent data indicate that chimpanzees, our closest living relatives, may have some degree of understanding of mental states as well (Suddendorf \& Whiten, 2001; Tomasello, Call, \& Hare, 2003). In an important sense, however, theory of mind appears to be a human cognitive specialization. There is compelling evidence that chimpanzees are capable of inferring from behaviors "lower-order" states such as intentions, perceptions, and desires, yet there is no strong evidence that any species other than our own can mentally represent "higher-order" psychological states such as thoughts, beliefs, and knowledge (Povinelli, Bering, \& Giambrone, 2000). In contrast, despite a highly active and generative research program within comparative psychology, the majority of controlled experimental findings continually demonstrate that nonhuman primates cannot reason about others' beliefs (Penn \& Povinelli, 2007; Povinelli \& Bering, 2002; Suddendorf \& Whiten, 2001).

These findings of a uniquely human theory of mind lead to a striking conclusion about our species' social evolution. Once our ancestors could reason about others' propositionally held beliefs about the world, this meant that they could also reason about others' propositionally held beliefs about other people in the world. Because the individual person is the vehicle by which genes are transmitted, natural selection would have favored the evolution of a subjective self that was largely focused on others' thoughts, beliefs, and knowledge about it. This is because these psychological states could be manipulated and cause others to act in ways that maximized reproductive success. This does not mean that individuals necessarily have insight into the ultimate purpose of their own adaptive self-presentation. Being acutely aware that other people have specific beliefs about us does not imply any privileged access to the evolutionary algorithms associated with managing these others' beliefs.

At some point or another, we have all been deceived by someone more socially savvy than ourselves, leading us to behave in ways counterproductive to our own self-interests. Likewise, we have all exploited someone else's naiveté by manipulating their beliefs for our own selfish reasons. In No Exit, such dynamics can be seen in the psychological tug-of-war between the characters of Garcin and Inez for the affections of Estelle. Inez, for example, in her futile attempts to woo the young woman, plants seeds of doubt in Garcin's mind about Estelle's assurances to him that, despite his refusal to fight in the war, she does not regard him as a coward.

ESTELLE: You haven't a coward's voice, or a coward's mouth, or a coward's hair. And it's for your mouth, your hair, your voice, I love you.

INEZ: She wants a man-that's as far as you can trust her-she wants a man's arms around her waist, a man's smell, a man's eyes glowing with desire. And that's all she wants. She'd assure you you were God Almighty if she thought it would give you pleasure.

GARCIN: Estelle, is this true? Answer me. Is it true?

If theory of mind (at least those higher-order aspects of the system that underlie human social cognition) is qualitatively unique to our species, as comparative data suggest, then so too must the phenomenal states arising from the system be peculiarly human. The evolution of theory of mind did not uniquely endow our species with social emotions, but theory of mind did introduce a very potent set of social emotions, including shame, pride, embarrassment, and humiliation, each dependent on "feeling" what other people think about us as individuals (Gil- 
bert, Pehl, \& Allan, 1998; Tangney, 2001). We can easily understand what Garcin is experiencing when, believing he is under constant surveillance by demons, he quietly wails, ". . . all those eyes intent on me. Devouring me."

\section{Epistemic Social Anxiety}

Epistemic social anxiety is the negative affective state that is associated with someone else knowing about-or threatening to know about - the self's undesirable attributes. This includes such things as moral offenses, questionable intentions, embarrassing foibles, or even physical defects. In No Exit, the character of Estelle, who has always been complimented on her beauty, is especially tortured by the absence of any mirrors in the drawing room:

When I talked to people I always made sure there was one near by in which I could see myself. I watched myself talking. And somehow it kept me alert, seeing myself as the others saw me... .

Painfully conscious, then, of how she appears to Inez and Garcin, Estelle allows the former to act as her looking glass in a clumsy attempt to apply lipstick. Inez is characteristically cruel to the young woman, however, telling her that she has a pimple on her cheek, which makes Estelle refer to herself as "simply foul." Then Inez says something crueler still:

Suppose I covered my eyes-as he is doing-and refused to look at you, all that loveliness of yours would be wasted on the desert air.

To the extent that natural selection has not endowed any other species with the capacity to represent others' beliefs and knowledge, and to worry about what they think about us as a consequence, epistemic social anxiety is a distinctively human type of psychological suffering.

There are, of course, likely to be robust, heritable individual differences in terms of degree of epistemic social anxiety within human populations. These superficial differences only disguise the fact, however, that most people care, usually very much, about what others know and think about them. People can suffer immensely when perceived negative aspects of their identity are publicly revealed or are on the verge of exposure. Shame may be one of the most powerful predictors of suicidal behaviors (Kalafat \& Lester, 2000; Lester, 1997; see also Baumeister, 1990). Human suicide appears unique in that we are the only species for which social evaluative appraisals contribute to selfdestructive behaviors of this kind (Bering \& Shackelford, 2004).

In No Exit, Estelle initially insists that some mistake has been made in her being sentenced to hell. After finally confessing her sins and making known to the others that which she so loathes about herself, she feels the weight of judgment upon her:

Everyone knows by now what I did to my baby. The crystal's shattered ... I'm just a hollow dummy; all that's left of me is the outside.

Garcin, meanwhile, is troubled by his posthumous reputation, particularly his inability to influence others' thoughts about him now that he is dead. He eagerly follows the gossip back on earth among his former newspaper associates:

"That chap Garcin's a coward." That's what they've decided, those dear friends of mine. In six months' time they'll be saying: "Cowardly as that skunk Garcin." You're lucky, you two; no one on earth is giving you another thought. But I-I'm long in dying.

\section{Witnesses and Self-Censor}

Our ancestors were faced with a problem that was foreign to any other animal on earth. If somebody-anybody-saw them engage in a socially proscribed event, they knew, and therefore they posed a threat to reproductive success as a carrier of this sensitive information. They could thus undo one's reputation by telling others who did not see the event occur. In No Exit, Inez defuses an encroaching sexual liaison between the other two characters by simply confirming her presence in the drawing-room:

But don't forget I'm here, and watching. I shan't take
my eyes off you, Garcin; when you're kissing her,
you'll feel them bore into you.

Similarly, Estelle recalls how her importuning lover, Robert, happened upon her at a Swiss villa in the act of drowning their baby:

There was a balcony overlooking the lake. I brought a big stone. He could see what I was up to and he kept on shouting: "Estelle, for God's sake, don't!" I hated 
him then. He saw it all. He was leaning over the balcony and he saw the rings spreading on the water-

Some evolutionary theorists have recently argued that subtle cues concerning observability factor prominently in reputation management. Burnham and Hare (in press), for example, found that people made more altruistic decisions in a task involving allocation of scarce resources even when the "witness" was simply an image of a robot with large human-like eyes. Similar results were reported by Haley and Fessler (2005), where participants behaved more generously on a computerized task when stylized eyespots were on the screen.

Knowing what others think about us similarly allows us to act adaptively in our dealings with them. Over the din of the two squabbling women in the drawing room, Garcin tries in vain to hear what his former newspaper associates have to say about him back on earth:

\begin{abstract}
Gomez was sprouting away as usual, standing in the center of the room, with all the pressmen listening. .I tried to hear, but it wasn't too easy. Things on earth move so quickly, you know. Couldn't you have held your tongues? Now it's over, he's stopped talking, and what he thinks of me has gone back into his head.
\end{abstract}

\section{Self-Disclosure is Irreversible}

Sharing sensitive information with trusted others can signal commitment in a personal relationship because disclosure inevitably renders one vulnerable to the person serving as the confidante (Pennebaker, 1990; Zech, Rimé, \& Nils, 2004). This is the tactic used by Sartre's character Garcin, who, after confessing his own sins, attempts to gain the others' trust by convincing them that he would never use such knowledge of their misdeeds against them. To create an atmosphere of mutual forgiveness and understanding is, he reckons, the best hope of dismantling the traps so carefully laid for them in hell:

So long as each of us hasn't made a clean breast of it-why they've damned him or her-we know nothing. Nothing that counts. [Why?] Tell us why. If you are frank, if we bring our specters into the open, it may save us from disaster.

Well, I, anyhow, can feel sorry for you, too. Look at me, we're naked, naked right through, and I can see into your heart. That's one link between us. Do you think I'd want to hurt you? I don't regret anything, I'm dried up, too. But for you I can still feel pity.
Human relationships are dynamic, however. Shifting alliances, changing goals, reshuffled hierarchies, and miscommunications can make even best friends turn against one another and become sworn enemies. This is the reason that self-disclosure is so difficult for people to practice even with intimate others (Pennebaker, 1990). Because personally sensitive information, once made public, can never be retracted, self-disclosure is potentially very risky. Estelle suffers the consequences of self-disclosure gone awry when she overhears her "bosom friend," Olga, back on earth revealing to a young man whom both women fancy what she did to her baby and how she drove her former lover to suicide:

\begin{abstract}
Oh, what's that? No, no. Don't tell him. Please, please don't tell him. You can keep him, do what you want with him, but please don't tell him about-that! All right. You can have him now. Isn't it foul, Garcin? She's told him everything, about Roger, my trip to Switzerland, the baby.
\end{abstract}

For the most part, people are vigilant in their protection of strategic information that could be used against them, either through purposefully deceiving others or through omission. Some evolutionary psychologists have even argued that self-deception may be adaptive in that it obtunds subtle behavioral tics that signal lying and thus give us away (Nesse \& Llyod, 1992; Trivers, 2000). Throughout various scenes in No Exit, Garcin is racked with self-doubt while trying to convince the other characters that desertion of his military responsibilities was an act of noble pacifism, a trait to be admired, rather than one of cowardice. Inez sees through this ploy:

What was your real motive? No doubt you argued it out with yourself, you weighed the pros and cons, you found good reasons for what you did. But fear and hatred and all the dirty little instincts one keeps darkthey're motives too. So carry on, Mr. Garcin, and try to be honest with yourself-for once.

\section{Other Minds Are Insufferably Out of Reach}

The ancient Sophists endeavored to convince themselves that the only real mind is one's own. This philosophical school of thought is called solipsism and was made famous by Bertrand Russell's antithesis, the 
argument by analogy (Russell, 1948). ${ }^{1}$ Psychologists Gallup and Platek (2002, p. 36) provide an updated cognitive science version of the argument by analogy, reasoning that "because humans share similar receptor mechanisms and brains that are organized in roughly the same way, there is bound to be considerable overlap between their experiences." Despite a long history of technically inaccurate terms being used in the social cognition literature (e.g., "intersubjectivity," "mind reading," and "perspective-taking") other minds still exist only in theory.

Minds are by their very nature psychologically contained, which is fundamental to what we may call representational loneliness. Representational loneliness occurs when the awareness of other minds comes into conflict with the awareness that the self can never be understood by others in its totality because it can never be experienced by anyone else (Humphrey, 2007). Unlike other forms of loneliness, it is exacerbated by the presence of others. ${ }^{2}$

Towards the end of the play, the door to the drawing room springs open, leading to a foreboding corridor. Rather than leaving for the unknown passages of hell, Garcin surprises us with his decision to stay, reasoning that his salvation lies in the room with Inez:

GARCIN: It's because of [Inez] I'm staying here. GARCIN: [You] know what wickedness is, and shame, and fear. There were days when you peered into yourself, into the secret places of your heart, and what you saw there made you faint with horror. And then, next day, you didn't know what to make of it, you couldn't interpret the horror you had glimpsed the day before. Yes, you know what evil costs. And when you say I'm a coward, you know from experience what that means. Is that so?

INEZ: Yes.

GARCIN: [I] couldn't leave you here, gloating over my defeat, with all those thoughts about me running in your head.

GARCIN: [So], Inez, we're alone. Only you two remain to give a thought to me. [Estelle]-she doesn't count. It's you who matter, you who hate me. If you'll have faith in me I'm saved.

INEZ: It won't be easy. Have a look at me. I'm a hard-headed woman.

Recent findings support Sartre's intuition on the effectiveness of convincing others that they are psychologically like us (GARCIN to INEZ: You are of my kind). Social psychologists studying persuasion have found that arguments framed as self-narratives, such as personal an- ecdotes and autobiographical stories, are especially effective at changing people's attitudes and lessening resistance (Green \& Brock, 2002). When people are on "the same page" they perceive a convergence of intentions that reduces epistemic anxiety and renders them less defensive.

\section{Conclusion}

To understand human psychological suffering, and ultimately to respond to it, we must first identify its species-specific causes. Although this may sound self-evident, the striking fact is that the field of psychology has never been focused on the far-ranging effects of evolved human cognitive specializations on mental well-being. In the present article, I have argued that theory of mind is both biologically adaptive and the common denominator in distinctively

\footnotetext{
${ }^{1}$ In his book Kinds of Minds, philosopher Daniel Dennett (1996) writes that roughly a third of his college students claim that as children they spontaneously questioned the existence of other minds. I routinely now pose the question to my own students and, like Dennett, I find that this naïve solipsism is more common than one might think. Those students who claim to have experienced it as children tend to describe their suspicion of other minds as coming to them abruptly. They describe, at some specific moment in their childhood, how they cast skeptical glances at the people around them, searching others' eyes for some irrefutable glimmer of a "soul" (see also Bloom, 2004).

${ }^{2}$ This is not to say that other social species cannot experience loneliness. A dog tethered to a tree and neglected by its owner is under psychological duress. Domesticated canines, through generations of artificial selection, are designed to live social lives alongside human caregivers. As Harry Harlo's notorious research program on socially deprived rhesus macaques amply demonstrated, some primates also display symptoms of severe psychological stress if physically removed from others for extended periods of time (see Dewsbury, 2000 for a review). Humans are no exception. The effects of solitary confinement on prisoners, for example, may include memory loss, severe anxiety, hallucinations, and delusions (Bonta \& Gendreau, 1990). We might call this form of loneliness, in which the socially isolated organism is maladapted to survive in a climate of social deprivation, organismic loneliness.

In contrast, representational loneliness is exacerbated by the presence of others. Although both forms of loneliness are psychologically painful for human beings, organismic loneliness may be preferred over representational loneliness, a "choice" reflected by those who lead reclusive lifestyles. Shame-prone individuals also tend to place greater physical space between themselves and others during social interactions (Gilbert \& McGuire, 1998). Presumably, it is less painful for some people to be alone than to be misunderstood.
} 
human types of psychological suffering. Just as there is remarkable continuity between the structures, abilities, and behaviors of closely related species, so too are there equally remarkable differences (Povinelli \& Bering, 2002).

If we wish to improve upon the human condition, we must therefore explore the private costs of human psychological adaptations that are regularly imposed on individual minds. Should we forget the importance of this task, we will find ourselves blindly condemned to the same awful fate as Garcin:

Open the door! Open, blast you! I'll endure anything, your red-hot tongs and molten lead, your racks and prongs and garrotes-all your fiendish gadgets, everything that burns and tears and flays-I'll put up with any torture you impose. Anything, anything would be better than this agony of the mind, this creeping pain that gnaws and fumbles and caresses one and never hurts quite enough. Now will you open the door?

It is almost as if Sartre is asking us - we who have an empirically informed understanding of human nature like no generation of psychologists before- to do precisely this, to open the door and properly introduce ourselves to our species' unique host of demons.

\section{References}

Baumeister, R. F. (1990). Suicide as escape from self. Psychological Review, 97, 90-13.

Bering, J. M. (2006). The folk psychology of souls. Behavioral and Brain Sciences, 29, 453-462.

Bering, J. M., \& Shackelford, T. K. (2004). The causal role of consciousness: A conceptual addendum to human evolutionary psychology. Review of General Psychology, 8, 227-248.

Bloom, P. (2004). Descartes' baby: How the science of child development explains what makes us human. New York: Basic Books.

Bonta, J., \& Gendreau, P. (1990). Reexamining the cruel and unusual punishment of prison life. In T. Flanagan (Ed.), Long-term imprisonment: Policy, science and correctional practice (pp. 75-94). London: Sage.

Burnham, T., \& Hare, B. (in press). Does involuntary neural activation increase public goods contributions in human adults? Human Nature.

Damasio, A. R. (2002). A note on the neurobiology of emotions. In S. G. Post, L. G. Underwood, J. P. Schloss, \& W. B. Hurlbut (Eds.), Altruism and altruistic love: Science, philosophy, and religion in dialogue (pp. 264-271). New York: Oxford University Press.
Dennett, D. C. (1996). Kinds of minds: Toward an understanding of consciousness. New York: Basic Books.

Dewsbury, D. A. (2000). Harlow, Harry Frederick. In A. E. Kazdin (Ed.), Encyclopedia of psychology (Vol. 4, pp. 62-64). Washington, DC: American Psychological Association.

Flavell, J. H. (1999). Cognitive development: Children's knowledge about the mind. Annual Review of Psychology, 50, 21-45.

Gallup, G. G., Jr., \& Platek, S. M. (2002). Cognitive empathy presupposes self-awareness: Evidence from phylogeny, ontogeny, neuropsychology, and mental illness. Behavioral \&Brain Sciences, 25, $36-37$.

Gilbert, P., \& McGuire, M. T. (1998). Shame, status, and social roles: Psychobiology and evolution. In P. Gilbert \& B. Andrews (Eds.), Shame, interpersonal behavior, psychopathology, and culture (pp. 99-125). New York: Oxford University Press.

Gilbert, P., Pehl, J., \& Allan, S. (1994). The phenomenology of shame and guilt: An empirical investigation. British Journal of Medical Psychology, 67, 23-36.

Green, M. C., \& Brock, T. C. (2002). In the mind's eye: Transportation imagery model of narrative persuasion. In M. C. Green, J. J. Strange, and T. C. Brock (Eds.), Narrative impact: Social and cognitive foundations (pp. 315-341). Mahwah, NJ: Lawrence Erlbaum.

Guthrie, S. (1993). Faces in the clouds: A new theory of religion. New York: Oxford University Press.

Haley, K. J., \& Fessler, D. M. T. (2005). Nobody's watching? Subtle cues affect generosity in an anonymous economic game. Evolution and $\mathrm{Hu}$ man Behavior, 26, 245-256.

Humphrey, N. (2007). The society of selves. Philosophical Transactions of the Royal Society, 362, 745-754.

Kalafat, J., \& Lester, D. (2000). Shame and suicide: A case study. Death Studies, 24, 157-162.

Kelemen, D. (2004). Are children "intuitive theists?" Reasoning about purpose and design in nature. Psychological Science, 15, 295-301.

Lester, D. (1997). The role of shame in suicide. Suicide \& Life Threatening Behavior, 27, 352361.

Nesse, R. M., \& Llyod, A. T. (1992). The evolution of psychodynamic mechanisms. In J. H. Bakow, L. Cosmides, \& J. Tooby (Eds.), The adapted mind: Evolutionary psychology and the generation of culture (pp. 601-624). New York: Oxford University Press.

Penn, D. C. \& Povinelli, D. J. (2007). On the lack of evidence that chimpanzees possess anything remotely resembling a 'theory of mind.' Philosophical Transactions of the Royal Society, 362, 731744. 
Pennebaker, J. W. (1990). Opening up: The healing power of expressing emotions. New York: Guilford Press.

Povinelli D. J., \& Bering, J. M. (2002). The mentality of apes revisited. Current Directions in Psychological Science, 11, 115-119.

Povinelli, D. J., Bering, J. M., \& Giambrone, S. (2000). Toward a science of other minds: Escaping the argument by analogy. Cognitive Science, 24, $509-541$.

Russell, B. (1948). Human knowledge: Its limits and scopes. London: Unwin Hyman.

Sartre, J. P. (1946/1989). No exit and other plays. New York: Vintage International.

Sartre, J. P. (1957). Existentialism and human emotions. New York: Philosophical Library.

Smart, L., \& Wegner, D. M. (2000). The hidden costs of hidden stigma. In T. F. Heatherton, R. E. Kleck, M. R. Hebl, \& J. G. Hull (Eds.), The social psychology of stigma (pp. 220-242). New York: Guilford Press.

Snyder, C. R., \& Lopez, S. J. (2007). Positive psychology: The practical and scientific explorations of human strengths. Thousand Oaks, CA: Sage.

Suddendorf, T., \& Whiten, A. (2001). Mental evolution and development: Evidence for secondary rep- resentation in children, great apes, and other animals. Psychological Bulletin, 127, 629-650.

Tangney, J. P. (2001). Self-conscious emotions: The self as a moral guide. In A. Tesser, D. A. Stapel, \& J. V. Wood (Eds.), Self and motivation: Emerging psychological perspectives (pp. 97-117). Washington, DC: American Psychological Association.

Tomasello, M., Call, J., \& Hare, B. (2003). Chimpanzees understand psychological states-The question is which ones and to what extent? Trends in Cognitive Sciences, 7, 153-156.

Trivers, R. (2000). The elements of a scientific theory of self-deception. In D. LeCroy \& P. Moller (Eds.), Evolutionary perspectives on human reproductive behavior. Annals of the New York Academy of Sciences, 97, 114-131.

Zech, E., Rimé, B., \& Nils, F. (2004). Social sharing of emotions, emotional recovery, and interpersonal aspects. In P. Phillippot \& R. S. Feldman (Eds.), The regulation of emotion (pp. 157-185). Mahwah, NJ: Lawrence Erlbaum.

Received April 25, 2006 Accepted February 26, 2007

\section{Correction to Logue (2007)}

In the article, "Meeting Current Challenges in Higher Education: The Need for More Psychologists" by A.W. Logue (Review of General Psychology, 2007, Vol. 11, No. 4, pp. 381-391), there are the following misprints:

- On page 389, right column, last paragraph, the second to last sentence should read "The goal now, however, will be to improve students' success, faculty's scholarship, and the future of their communities".

- On page 386, right column, third paragraph, line six, "psychologist-administrators" should appear as "psychologist administrators"

- On page 390, right column, the Logue 2006 reference should read "[Survey of fields of Middle States Commission accredited New York State institutions of higher education chief academic officers and presidents]" 